\title{
Globální změna klimatu: možnosti didaktického zpracování tématu na úrovni středních škol
}

\section{Barbora Duží}

Envigogika 2012/VII/1- Recenzované články/ Reviewed Papers

Publikováno/Published 31. 05. 2012

DOI: http://dx.doi.org/10.14712/18023061.68

\begin{abstract}
Abstrakt:
Text se zabývá možnostmi zpracování tématu globální změny klimatu ve výuce na úrovni středního školství. v první části se zaměřuje na téma globální změny klimatu a jeho využití v environmentální výchově. Představuje zde koncept "social amplification" a jakým způsobem souvisí s percepcí a interpretací environmentálních témat. Další část obsahuje návrh pracovní metodiky pro hodnocení a analýzu různorodých informačních zdrojů pro potřeby výuky. Využívá několik hodnotících kritérií, např́íklad hodnotící škálu alarmistický skeptický. Nakonec představuje praktickou aplikaci metodiky analýzy na př́kladě několika informačních pramenů. Obsahuje také dvě př́lohy - didaktickou analýzu učebnice „Environmentální výchova" a ukázku výukové jednotky „Planeta Země: seznamte se".
\end{abstract}

\section{Klíčová slova:}

Globální změna klimatu - environmentální výchova - didaktika

\begin{abstract}
:
The work deals with "global climate change" and methods how to work it up in the process of education. This topic is suitable for using in cross-disciplinary theme Environmental education. The aim of the work is to show its interdisciplinary character and diffusing through various educational themes.

The first part of the paper describes the key terms and introduces the concept of social amplification. Then the paper analyzes various resources and its usefulness for education with using concept of social amplification for alarmistic - skeptical scale of interpretation information about global climate change. Another part creates work version of quick analysis of information sources for using in education. Work ends up with recommendation for practical using in education. Moreover, appendix includes didactic analysis of textbook "Environmental Education" and draft of educational unions concerning to topic global climate change "Planet Earth: Introduction".
\end{abstract}

\section{Key words:}

Global climate change, environmental education, didactics, social amplification 


\section{Úvod}

Problematika globální změny klimatu se stala běžnou součástí rámcových vzdělávacích programů a učebnic nejen druhého stupně základních škol, ale především středních škol. Toto téma je obvykle vyučováno v rámci sady globálních problémů a také tématu udržitelného rozvoje. Jednotlivé tematické okruhy mohou být také integrovány do jednotlivých předmětů (např. zeměpis, dějepis, základy společenských věd). v rámci prưřezového tématu environmentální výchova [1], které na vyšší úrovni integruje znalostní výstupy jiných předmětů, se zařazení tématu globální změna klimatu jeví jako nejvhodnější.

Dle mého názoru představuje klimatický systém jedno z nejkomplexnějších témat nejen pro studenty, ale zejména pro pedagogy, jejichž úkolem je toto téma vhodným zpưsobem didakticky a obsahově zpracovat. Má interdisciplinární rozměr a pro jeho uchopení je zapotřebí zapojení nejvyšších náročných myšlenkových operací, jako je hodnotící posouzení a syntéza, jak uvádí taxonomie kognitivních cílů dle B. S. Blooma[2] (Obst, 2006: 53-54). v oblasti výukových cílů je zde kladen velký důraz na postojové výukové cíle, tj. vytváření hodnot a postojů k dané problematice.

Stručně řečeno, globální změna klimatu je složité, velmi těžko uchopitelné téma a porozumět tomuto fenoménu není jednoduché. Vzhledem $k$ šíri i aktuálnosti problematiky klimatické změny jsem se zaměřila především na počáteční část práce pedagogů, která spočivá $v$ analýze různých informačních pramenů. Ty jsou vybírány jak z hlediska jejich vhodnosti pro zařazení do výuky, tak z pohledu inspirace pro samotné pedagogy, kteří by si měli nebo chtěli rozšiřit přehled a nestačí jim předložené informace ve stávajících učebnicích. Zvláště u tak dynamicky se rozvíjejícího oboru jako je změna klimatu a jeho dopady. Doplnění standardního obsahu výuky o další prameny a zdroje je potřebné především na úrovni středního školství, kde by studenti měli rozvíjet a uplatnit především kompetence k řešení problémů, sociální a občanské kompetence, včetně schopnosti zaujetí kritického postoje, srovnávání a rozlišování různých zdrojů informací.

\section{Vymezení pojmů a zasazení problematiky do kontextu}

Ke globální změně klimatu Ize totiž stěží přistupovat jednoznačně a prezentovat ji jako ohraničené téma s jasným a reálným řešením. Řada prací se zabývá výzkumem, do jaké míry je změna klimatu již zažívána v každodenním životě a do jaké míry zatím pouze prezentována na teoretické rovině prostřednictvím statistických grafư zobrazujících časové řady, meteorologické veličiny či klimatické modely. Souvisí s tím také percepce závažnosti změny klimatu jako problému. Pro řadu lidí představuje změna klimatu vzdálený problém, který se jich osobně netýká, pokud nezakouší opakovanou negativní zkušenost spojenou s jeho projevy (viz. Nicholson-Cole, 2005; Weber, 2010). Globální změna klimatu je však ve vědecké obci považována za tzv. megaproblém, jehož typickými vlastnostmi jsou: jedinečnost ve svém rozsahu (zasahuje celou biosféru), delší časová řada pro jeho indikaci a abstraktní povaha, i když projevy jsou již čitelné na konkrétních místech (srovnej Harper 2011; Weber, 2010). s tím souvisí další otázky. Klimatické modely pracují s časovým horizontem cca 50 až 100 let a jsou zatíženy určitou nejistotou - jsou lidé schopni svá rozhodnutí směřovat s ohledem na tak vzdálený časový horizont?

Jak vlastně toto téma uchopit? Nepolapitelný a rozpínající se vzduch, neustále se měnící počasí? Co je vlastně špatného na oxidu uhličitém, proč je v současnosti prezentován jako "znečištující plyn", když byl pưvodně chápán jako "životodárný" plyn, díky němuž a rostlinám zde život existuje $v$ současné podobě? Zdaleka jsem nevyčerpala všechny otázky, a v této souvislosti je třeba připustit skutečnost, že oblast vzdělávání se musí smířit s tím, že bude prezentovat "nevyřešitelné" problémy nebo jen dílčím zpưsobem rešitelné environmentální výzvy, kdy globální změna klimatu představuje víc než typický príklad. 
Zhruba od druhé poloviny 20. století se ve větší míře objevují práce[3], které upozorňují na tempo a rozsah využívání životního prostředí lidskou společností, které začínají dosahovat závažných rozměrů a množství problémů narůstá tak, že začínají přesahovat hranice národních států a stávají se globálními.

Postupně se do popředí zájmu dostává také otázka vlivu lidské společnosti na klimatický systém. Přestože klimatický systém planety podléhá určité přirozené variabilitě, člověk je vnímán jako stále výraznější činitel, mající také vliv na klimatické procesy. Pod pojmem globální změna klimatu (GZK) se rozumí "dlouhodobá odchylka klimatických parametrů Země, např. teploty, srážek, rychlosti větru, od průměru a trendů, které charakterizovaly naši planetu přibližně do počátku 20. stol." (Marek a kol., 2010:18). u GZK je zdůrazněna právě antropogenní role. "Měnící" vliv na klimatický systém na lokální i globální úrovni má především uvolňující se skleníkové plyny a změna využívání přírody a krajiny (průmysl, zemědělství, doprava, urbanizace, energetika apod.).

Kromě toho je v literatuře používán termín "změna klimatu" / "klimatická změna", víceméně jako kratší verze termínu " globální změna klimatu".

Nicméně vědecká terminologie v poslední době pracuje stermínem "globální změna". Odpovídá rozsahu změn, ke kterým dochází: "široké spektrum biofyzikálních a socioekonomických změn, které mění fungování Země jako systému v planetárním měřítku" (Globální změna v kostce, 2010). Její součástí je i změna klimatu a za jejího výrazného činitele/hybatele je považován člověk.

Téma globální změny klimatu opustilo hranice vědeckého bádání již na sklonku 70. let 20. století. Dostalo se do sféry zájmových skupin (politické skupiny, nevládní ekologické organizace, mezinárodní organizace), které se snaží prosadit politická a faktická opatření. Prvním větším mezinárodním závazkem se stala Rámcová úmluva OSN o změně klimatu, přijatá v roce 1992 na Summitu Země v Rio de Janeiru. Významnou roli ve veřejné publikaci tohoto tématu má Mezivládní panel pro změnu klimatu (IPCC), který na mezinárodní úrovni shromažd'uje výsledky vědeckého bádání, hodnotí environmentální a sociální důsledky různých scénářư a navrhuje opatření. Pro tyto účely pravidelně vydává tzv. hodnotící zprávy, které mimo jiné obsahují doporučení využitelná pro politické rozhodování.

Informace jsou předávány různými kanály směrem k veřejnosti a jsou také různorodě vnímány a interpretovány, záleží na daném sociálního prostředí. Tyto interpretace se mohou týkat např́klad závažnosti problému jako takového, míře rizika a nebezpečí, dopadů změny klimatu na prírodní a sociální systémy, otázky reakce společnosti na tento problém, projekce budoucího vývoje apod. Výzkumné studie se $v$ této oblasti mj. zabývají konceptem "zesilování" [4] informace, v anglické terminologii vhodně označeném jako "social amplification" (Kasperson, 1988). Informace je transformována podle toho, jakými informačními kanály prochází, jaká zájmová skupina s ní pracuje, za jakým účelem ji zpracovává, interpretuje a vysílá dále - je zde vzat v úvahu sociální kontext[5]. Informace mohou být vytrženy z kontextu, některé zesíleny, jiné naopak zeslabeny, účelově filtrovány apod. (Kasperson, 1988: 181). s nadsázkou lze ríct, že informace svým zpưsobem "žije".

Jedním z klíčových dilemat vědců, ekonomů a politických představitelů je hledání způsobů, jak se vypořádat s předloženými informacemi, týkajícími se závažnosti klimatické změny a jejího dopadů na lidskou společnost, a jaká opatření realizovat ve vztahu ke změně klimatu, aby byla smysluplná a efektivní. Obecně se přistupuje ke dvěma základním druhům strategií, mitigačním a adaptačním a jejich vhodným kombinacím. Mitigační opatření spočívají především v technologických změnách a opatřeních, která snižují spotřebu zdrojů a množství emisí skleníkových plynů na jednotku výstupu. v poslední době se však stále více ukazuje, že klimatickou změnu se nepodaří včas odvrátit a jsou navrhována adaptační opatření, spočívající ve snížení zranitelnosti společenských a přírodních systémů vưči současným nebo očekávaným projevům globální změny klimatu (upraveno dle Voženílek a kol., 2010:28). v neposlední řadě se objevují technokratické 
návrhy opatření z dílny geo-inženýringu, jejichž cílem je působit proti změně klimatu prostřednictvím sady technických opatření. Aplikace těchto opatření je však na hranici scifi, jsou extrémně drahá a jejich aplikace mư̌̌e zpưsobit nepředvídatelné environmentální problémy [6] (Harper, 2011:77).

\section{Globální změna klimatu a environmentální výchova}

Z uvedeného popisu je zřejmé, že současná společnost vytváří problémy a staví před studenty výzvy, které nevyřeší tím, že se "nabiflují učební látku a napíší úspěšně test nebo uspějí u ústní zkoušky", ale tím, že obstojí při jejich řešení v každodenním životě. z tohoto důvodu byla do vyučování zařazena tzv. prưřezová témata - pro globální změnu klimatu je relevantní především environmentální výchova. Podstatou prưřezových témat je zdůraznění především jejich výchovné funkce ve vzdělávání žáků. Podle Matějčka (Matějček, 2007:1) se jedná o "výchovné propojení mezi všemi nebo alespoň větším počtem předmětů na škole, ale také mezi vyučováním a životem školy i životem mimo školu". "Prưřezovost"[7] se tedy váže nejen na předměty vyučované ve škole, ale také na život v současné globalizované a dynamicky se měnící společnosti. Výhodou prưřezového tématu je možnost aplikace "volnějších" didaktických a aktivizujících metod, jako jsou například problémové a projektové metody. Obsah výuky je zaměřen na vybrané aspekty problému a integrování látky vyučované v jiných předmětech na vyšší úroveň.

Prưřezové téma Environmentální výchova je do školského systému zařazeno díky Metodickému pokynu MŠMT k zajištění environmentálního vzdělávání, výchovy a osvěty (EVVO) z roku 2001. Tento pokyn byl aktualizovaný v roce 2008, kdy se přizpůsobil transformaci vzdělávacího systému na rámcové vzdělávací programy, v textu je používán zkráceně termín "environmentální výchova"[8]. Environmentální výchova (anglicky Environmental Education) je jedním z nástrojů tzv. preventivní ochrany životního prostředí.

Pro potřeby této práce používám definici environmentální výchovy z Metodického pokynu MŚMT (2008:2), která vymezuje environmentální výchovu jako "všestranné rozvíjení klíčových kompetencí v kontextu vzájemných vztahů mezi člověkem a životním prostředím s dưrazem na vyvážené působení nejen společenských, ale také přírodních faktorů. Jde tedy o motivaci s poskytnutím př́ležitosti k dosažení znalostí, dovedností, postojů a návyků k ochraně a zlepšování životního prostředí, k utváření hierarchie životních hodnot slučitelných s udržitelným rozvojem, k smysluplnému jednání a tvořivosti ve prospěch životního prostředí, k udržitelnému zpưsobu života a udržitelným vzorcům chování jednotlivců, skupin i společnosti jako celku. Nezanedbatelná je i provázanost environmentální výchovy s problematikou zdraví a zdravého životního stylu.

Bez pochopení základních stavebních kamenů poznání týkajících se planety Země a jejích environmentálních podmínek nelze na odpovídající úrovni komunikovat o změně klimatu. Pro tento účel jsem využila struktury učebního textu pro prưřezové téma Environmentální výchova (Matějček, 2007), kde poměrně uceleně a systematicky provází studenty čtyřmi tematickými celky, postupně skládajícími mozaiku poznávání životního prostředí, přírody a vztahů s lidskou společností. Přispívá zde také k poznání klimatického systému Země. Jedná se o Základní podmínky života, Ekosystémy a jejich funkce, Lidské aktivity a problémy životního prostředí, Vztah člověka k prostředí.

Každý tematický celek obsahuje informace, týkající se poznávání a porozumění souvislostem mezi stavem životního prostředí, klimatickým systémem $v$ širším slova smyslu a problematikou vlivu lidské civilizace. Níže uvádím stručný výčet informací, které jsem analyzovala jako vysoce relevantní pro oblast klimatu. 


\section{Základní podmínky života}

$\mathrm{V}$ rámci kapitoly jsou $\mathrm{v}$ učebnici postupně představeny tato témata: postavení planety Země ve vesmíru, přírodní zdroje, základní složky životního prostředí - voda, ovzduší, půda, biodiverzita (Matějček, 2007:4-14). Ve výuce mưže tato část sloužit pro zdůraznění výjimečnosti postavení planety Země, umožňující vznik a vývoj organického života[9].

\section{Ekosystémy a jejich funkce}

V této části jsou představeny základní procesy $v$ ekosystémech, koloběhy látek a toky energií, biogeochemické cykly prvků včetně uhlíku, rozdělení ekosystémů na Zemi podle klimatických podmínek.

\section{Lidské aktivity a problémy životního prostředí}

Zde následuje výčet hlavních lidských aktivit (průmysl, zemědělství, doprava, odpady) a jejich vliv na prírodu, krajinu, životní prostředí a zdraví člověka, včetně prokazatelného vlivu na klimatický systém planety.

\section{Vztah člověka $\mathrm{k}$ prostředí}

Tento celek je v největší míře zaměřen na postojové výukové cíle. Je zde rozebrán nerovnoměrný ekonomický rozvoj a životní úroveň obyvatel Země $v$ různých regionech, vliv globalizace na životní prostředí a společnost. Nejen vědeckou, ale také etickou a hodnotovou stránku přístupu ke světu pak představuje oblast ochrany přírody a krajiny a hledání cest $k$ takovému chování, které by méně zatěžovalo přírodu a životní prostředí [10].

Pro zpracování výukové jednotky na jakoukoliv oblast průřezového tématu Environmentální výchova je vhodné tuto základní osnovu doplnit studiem vybraných pramenů, analyzovat jejich didaktickou efektivitu, obsahovou stránku a vhodným způsobem je didakticky zapracovat.

Závěry empirických výzkumů, zaměřené na testování znalostí a postojů žáků či studentů ke globální změně klimatu ukazují, že řada žáků a studentů si na základě nepřesného osvojení učiva mưže vytvářet chybné koncepce (miskoncepce). Správná identifikace mylných představ by mohla přispět $k$ tomu, jak následně navrhnout vhodné nástroje ve výuce, které by přispěly $k$ jejich opravení. v českém prostředí se těmito výzkumy zabývají např. Kopp, Beránková (2012) [11].

Mezi další vhodné techniky, jak zjištovat úroveň znalostí, základní představy nebo postoje ke změně klimatu patří kromě testů, které zvolili Kopp a Beránková, také vizualizace a mentální modely. Vizualizace se používají pro konfrontaci respondentů s navrženou podobou budoucnosti, tzv. "futurescopes" (Nicholson-Cole, 2005). Ty jsou realizovány nejen pro účely výuky, ale také pro praktickou politiku, plánování a rozhodování ve veřejné sféře. Zjištóvání mentálních modelů o vybraných tématech změny klimatu zapojuje respondenty prímo do jejich tvorby. Testovány jsou často mentální modely a základní představy o fungování principu skleníkového efektu (např. Shepardson a kol. 2011). Na základě zjištění, jak studenti chybně konstruovali princip skleníkového efektu, autoři rovněž podrobili kritice i schémata použitá $v$ některých učebnicích a identifikovali možné zdroje pokřivení konstrukce problémů již u jejich autorů (Nicholson-Cole, 2005:2) 
Mezi prezentací informací v učebnicích a následným porozuměním nebo vytvářením mylných představ by měla $v$ ideálním případě existovat jistá koevoluce. Výše zmíněné výzkumy mohou přispět nejen ke zjištění případných miskoncepcí u studentů, ale také k odhalení chybných způsobů prezentace informací v učebnicích, aby mohly být následně opraveny.

\section{Jakým způsobem Ize hodnotit prameny a jak k nim přistupovat pro využití ve výuce}

Na téma změny klimatu existuje mnoho různorodých pramenů, mimo jiné z důvodu jejího interdisciplinárního charakteru a široké variability přístupů k jejímu řešení. Tak jako mưžeme doplnit či rozšírit o klimatický rozměr obsah řady předmětů (např́klad dějepis, základy společenských věd) [12], potřebujeme zároveň propojit poznatky z různých předmětů, abychom jim mohli lépe porozumět (především biologie, geografie, chemie, fyzika). Uvedený výčet nelze považovat za reprezentativní. Každý z nich přináší jiný pohled na věc, jinou část mozaiky.

Za důležité také považuji odlišit tzv. vědecká data a jejich interpretace. Vědecké prameny by měly vycházet z dlouhodobého výzkumu, pozorování počasí, vývoje klimatu, přírodních podmínek Země, přírodního, potažmo životního prostředí a především neustávajícího kritického procesu ověřování či vyvracení hypotéz[13].

Při studiu materiálů různých zájmových skupin (nevládní ekologické organizace, politické či ekonomické skupiny nebo interpretace rưzných osobností, samotných vědcứ apod.) bychom měli být mírně kritičtí. Je třeba počítat s tím, že tyto skupiny sice mohou využívat vědecké podklady, ale do určité míry nezastávají nezávislý pohled - interpretují informace tak, aby odpovídaly jejich zájmům. Jak již bylo zmíněno výše - zesilují určité informace dle svých potřeb. Vytahují informace, které mohou využít pro svou argumentaci a zapadají do jejich názoru.

Zastánci krajního spektra názoru na problém si vysloužili přízvisko alarmisté versus skeptici. Mezi nimi samozřejmě existuje široká škála názorù, přiklánějící se k té či oné straně.Dle alarmistů je změna klimatu jednoznačně způsobena antropogenním vlivem a je nutné ji všemi prostředky odvrátit, jinak společnosti hrozí katastrofický scénář budoucího vývoje. v klimatických a jiných modelech je vždy obsaženo několik scénářù - alarmisté se zaměří na ty nejpesimističtější předpovědi nárưstu hladiny moří a další environmentálních údajů. Jejich jazyk je "akční", například mohou volat po boji proti změnám klimatu a po radikální změně přístupu k řešení problému, je zde kladen velký dưraz na zapříčinění negativního stavu lidskou společností, často obsahuje také morální apel na obecné rovině i směrem k jednotlivcům (upraveno a doplněno dle Voženílek a kol., 2010:22-23). z pohledu konceptu social amplification se jedná o výrazné zesílení informací negativní stránky globální změny klimatu.

Skeptici zase spíše zdůrazňují názor, že klimatická změna je výsledkem přirozené variability klimatu, a tudíž opatření směřující k snížení emisí skleníkových plynů považují za neefektivní př́padně zbytečné a zaměřují se naopak na některé pozitivní efekty klimatických změn - například zvětšení plochy zemědělské pưdy $v$ pưvodně klimaticky nepříznivých oblastech $z$ důvodu oteplení atmosféry apod. (upraveno a doplněno dle Voženílek a kol., 2010:22-23). z pohledu social amplification tedy problém zeslabují a zlehčují.

Zcela individuální kategorií jsou média, at už se jedná o televizní, internetové zpravodajství, noviny, časopisy a podobně. Jejich cílem je primárně upoutat pozornost, takže je zde velká pravděpodobnost překrucování (manipulací s) informací v největší míře - vyhovují informace katastrofického znění nebo vyjadřující nějakou senzaci. Zajímavý je také jejich "sezónní výskyt" - když se projednávají politická opatření na mezinárodních 
setkáních týkajících se klimatu, téma je najednou aktuální. Pokud dojde k nějaké katastrofické události týkající se extrémních klimatických jevů (povodně, hurikány, tajfuny, sucha, horka), tak rovněž zaplňují mediální prostor[14].

Nyní se dostáváme k otázce, jak hodnotit dané prameny z hlediska jejich relevantnosti, použitelnosti ve výuce, adekvátnosti vzhledem k věku a studijní úrovni apod.

Obecně se hodnocení pramenů pro potřeby výuky na školách soustřed'uje především na učebnice. v tomto směru například Obst (2006), Maňák, Klapko (2006) využívají hodnocení prostřednictvím kvantitativní metod a zaměřují se na obsahovou stránku (např. hodnocení obtížnosti výkladového textu, syntaktické obtížnosti apod.) nebo na měření didaktické vybavenosti učebnic, především struktury, zařazení obrázků a dalších didaktických komponent.

Je třeba připustit, že pro potřebu rychlého zhodnocení učebnice z hlediska využití ve výuce jsou tyto metody př́liš komplikované. Autorka zde vytvořila spíše kvalitativní, rychlou metodiku pro analýzu pramenů. Soustředí se v ní především na orientační, slovní ohodnocení pramenů z několika hledisek:

Anotace : stručné seznámení s obsahem a zaměřením publikace.

Využitelnost : zaměření na to, v čem je publikace využitelná a přínosná pro výuku.

Informační zkreslení : orientační příměr pro názorové zařazení (zeslabení - zesílení informace) ve škále: silně alarmistické - alarmistické - mírně alarmistické - neutrální mírně skeptické - skeptické - silně skeptické.

Obtížnost textu: odpovídá ve zjednodušené formě na otázku, do jaké míry je výkladový text obtížný pro porozumění ve škále: silně odborný - odborný - přiměřený zjednodušený.

\section{Práce s informačními prameny: ukázka analýzy a další doporučení}

Níže uvádím příklady zpracování několika relevantních pramenů, dle mého názoru vhodných pro didaktické zpracování ve výuce. Seznam je vytvořen na základě subjektivního, osobního výběru a zdaleka není vyčerpávající.

MAREK, V. M. a kol. Uhlík v ekosystémech České republiky v měnícím se klimatu. Praha: Academia, 2011. ISBN 978-80-200-1876-2

\section{Anotace:}

Publikace je zprávou o výstupech vědecké činnosti týmů Akademie věd České republiky a jejich výzkumných grantových projektů Czech Terra, ForChange, CzechCarbo.

Tato publikace se zaměřuje na problematiku globální změny klimatu a nejnovější poznatky o cyklu uhlíku.

První kapitola přináší obecný úvod do tématu klimatické změny, druhá kapitola se zaměřuje na klimatologický kontext, včetně klimatických modelů. Třetí kapitola se soustředí na tzv. eko-fyzikální aspekty výskytu a ukládání uhlíku. Další kapitoly se pak zabývají souvislostmi mezi změnou krajiny a klimatem, globálním cyklem uhlíku, antropogenními emisemi skleníkových plynů apod. Zajímavé jsou také závěry sociologického výzkumu zaměřeného na postoje různých sociálních skupin ke klimatickým změnám. 


\section{Využitelnost:}

Publikace přináší nejaktuálnější výsledky vědeckého bádání, jsou zde zohledněny výsledky rưzných vědeckých disciplín, didaktický význam mají zejména různé tabulky a grafy. Oceňuji zejména komplexní pohled na problematiku - není zde uveden jen problém tzv. emisí skleníkových plynů z průmyslu, ale také role př́rody a krajiny jako uhlíkových úložišt $t^{\prime}$ (tzv. sink), fotosyntéza rostlin apod. Vzhledem k tomu, že jde o vědeckou publikaci, poměrně velká část textu je náročná na porozumění a je úzce zaměřená na určité téma. Jsou zde uvedeny také závěry měření ze stanice dlouhodobých impaktových experimentů na Bílém Kříži, kde je analyzován vývoj smrkového porostu v podmínkách odpovídajících klimatu za 50 let - potenciálně vhodné na exkurzi.

\section{Informační zkreslení:}

Neutrální až mírně alarmistické (obsahuje pasáže poukazující na závažné porušení klimatické rovnováhy lidskou společnosti).

\section{Obtížnost textu:}

Silně odborný.

\section{Závěr analýzy:}

Pro svoji poměrně silnou obtížnost textu je publikace využitelná jen zčásti, zejména obrázky, grafy a jejich interpretace. Pro využití jsou také vhodné pasáže zabývající se rolí prírody a krajiny jako úložiště uhlíku. Možnost exkurze na stanici na Bílém Křiži, případně jiné meteorologické stanice, kterými disponuje CzechGlobe.

\section{REID, Walter W. a kol. Ekosystémy a lidský blahobyt. Syntéza. Praha: Centrum UK pro životní prostředí, 2005. ISBN 80-239-6300-7}

\section{Anotace:}

Jedná se o český překlad práce vědeckého týmu organizace World Resources Institute, která přináší komplexní pohled na změny ekosystémư za posledních 50 let, zisky a ztráty plynoucí z těchto změn a nástin vývoje do budoucnosti. Tato publikace je zmíněna především z toho důvodu, že přináší nový pohled na roli přírodních systému pro lidskou společnost - tzv. ekosystémové služby a jejich vazby na lidský blahobyt. Mezi ekosystémové služby z hlediska klimatu patří např. schopnost oceánů, lesních lučních ekosystémů, půdy a dalších ukládat uhlík, biogeochemické cykly prvků, koloběh vody apod.

\section{Využitelnost ve výuce:}

Didakticky hodnotné jsou především různé grafy a tabulky znázorňují antropogenní vliv na stavy ekosystémů (např́klad změna pokryvu lesů, lovišt́ ryb, hospodářsky obhospodařované půdy, výlovu, obsahu chemických látek na celosvětové úrovni). Dále je zde znázorněn nový pohled na úlohu ekosystémů pro lidský blahobyt, ocenění jejich služeb (zásobovací, regulační, kulturní, podpůrné) a hodnocení změn (nejen z ekonomického pohledu), kterými prochází, včetně důsledků pro lidskou společnost.

\section{Informační zkreslení:}

Neutrální až mírně alarmistické.

\section{Obtížnost textu:}

Odborný. 


\section{Závěr analýzy:}

Publikace je opatřena ve velké míře tabulkami, grafy, mapami, které mají vysokou vypovídající hodnotu. Přestože jde o jednu z metod ekonomického oceňování prírody a ekosystémových služeb, což by mohlo být kritizováno jako př́liš úzký pohled na problematiku, z uvedeného popisu je zřejmé, že lidská společnost na těchto službách a zdrojích existenčně závisí. Čísla vypovídají jasně o tom, že kvalita a schopnost ekosystémových služeb se zhoršuje $v$ dưsledku nadměrného civilizačního tlaku.

\section{KUTÍLEK, Miroslav. Racionálně o globálním oteplování. Praha: Dokořán, 2008. ISBN 978-80-7363-183-3}

\section{Anotace:}

Tato publikace není odbornou publikací v pravém slova smyslu. Napsal ji sice významný vědec, obsahuje citace vědeckých pramenů, ale je zde patrná jistá interpretace těchto informací, která autora raadí spíš do tábora skeptikủ. Kutílek zde vyjadřuje skepsi k "přesnosti" měření globální teploty nebo hladiny oceánů, upozorňuje na to, že klimatický systém je mnohem složitější, než si vůbec dovedeme představit, a zredukovat jeho vývoj do několika modelů, apeluje na mnohem větší opatrnost a obezřetnost při interpretaci výsledků měření a antropologického vlivu na klimatické změny. Podrobuje jisté kritice také závěry IPCC.

\section{Využitelnost:}

Kniha může sloužit jako zdroj informací o klimatických podmínkách Země. Velmi užitečné jsou zde informace týkající se popisu prímých a nepř́mých metod měření obsahu oxidu uhličitého. Další důležitou kapitolou je analýza příčin, které mají/měly v historii vliv na změnu klimatu, vyjma člověka. s ohledem na odborné zaměření autora jako pedologa je zde zdůrazněna role půdy.

Informační zkreslení:

Skeptické.

\section{Obtížnost textu:}

Přiměřený.

\section{Závěr analýzy:}

Nelze jednoznačně říct, že se jedná o účelové zkreslování informací díky silné odborné erudici autora. Navíc se kriticky staví k dosavadním vědeckým postupům a interpretacím uznávaného vědeckého tábora včetně IPCC. v publikaci také odsuzuje katastrofické scénáře, které bývají s prognózami vývoje změny klimatu spojovány. Text vhodný pro odvážné studenty, kteří se nebojí být konfrontováni s různými názory.

Další, již stručnější analýzy:

GORE, Al. Nepříjemná pravda. Naše planeta v ohrožení - globální oteplování a co s ním můžeme udělat. Praha: Argo, 2007. ISBN 978-80-7203-868-8

\section{Anotace:}

Tato kniha př́mo "bije na poplach" - psána částečně osobním, částečně reportážním stylem. Publikace ukazuje na řadu varovných príkladů změny klimatu, její obsah se prolíná s osobní historií a zkušenostmi. 


\section{Využitelnost:}

Publikace je didakticky cenná zejména pro svůj reportážní styl a uvedené príklady změny klimatu včetně barevných fotografií. Její jazyk vhodný pro obsahovou analýzu textu a jazykových prostředků, které jsou zvoleny.

\section{Informační zkreslení:}

Silně alarmistické.

\section{Obtížnost textu:}

Přiměřený.

\section{LOMBORG, Björn. Zchlad'te hlavy. Skeptický ekolog o globálním oteplování.} Praha: Dokořán, 2008. ISBN 978-80-7363-188-8

\section{Anotace:}

Kniha přináší ekonomický pohled na věc - tj. hledání priorit a balancování nákladů a př́nosů rưzných opatření při zavádění rozlišných scénářů opatření. Převládajícím názorem je podpora ekonomického rozvoje, protože bohatší společnost bude $v$ budoucnu disponovat finančními zdroji, vědci a technologiemi pro řešení globálních problémů včetně klimatických změn. Podporuje také mohutně rozvoj čistých technologií.

\section{Využitelnost:}

Didakticky zajímavý je ekonomický pohled na věc, který zdůrazňuje, že nemáme finanční prostředky $\mathrm{k}$ tomu, aby "všichni řešili všechno" a je třeba zvolit priority. Lomborg neodmítá závažnost klimatických změn, ale poukazuje na další, dle jeho názoru palčivější problémy. Představuje zde i morální dilema, např́klad pokládá otázku, do jakých oblastí je třeba investovat finanční prostředky - do zmírnění chudoby, vzdělávání, boje proti nemocem nebo do technologií na snížení emisí oxidu uhličitého apod.

\section{Informační zkreslení:}

Mírně skeptické.

\section{Obtížnost textu:}

Přiměřený.

\section{Srovnání}

Z hlediska konceptu zeslabení - zesílení informace, odpovídající škále skeptický alarmistický bychom mohli výše uvedené publikace seřadit takto [15]:

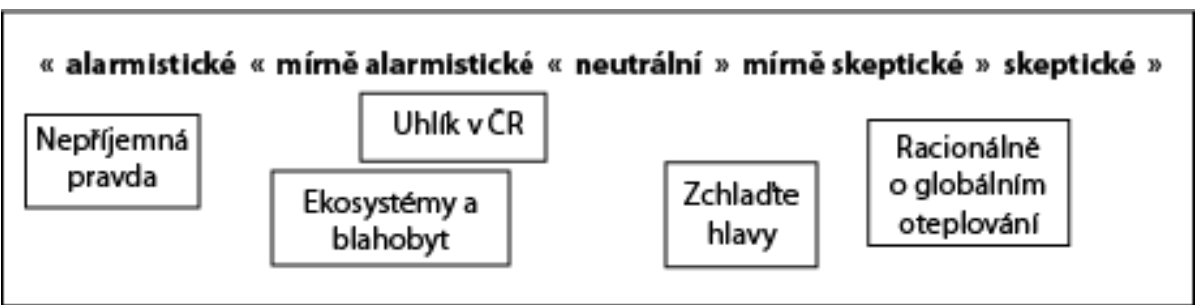

Následuje stručný výčet elektronických informačních pramenů bez analýzy: 
Mezi další informační prameny, které Ize využít ve výuce, patří webové stránky ekologických organizací a středisek ekologické výchovy, které obsahují:

\section{Klimatická koalice, 2007. [online] [cit. 2011-6-8] dostupné z http://www.zmenaklimatu.cz}

Webové stránky Klimatické koalice nevládních ekologických organizací, které spojuje téma změny klimatu. Obsahuje aktuální zpravodajství, vědecké a jiné prezentace, je zde možnost si vypočítat kalkulačkou tzv. uhlíkovou stopu[16]. Obsahuje také výukové materiály pro školy, odkazy na krátké filmové spoty.

Výstava Prima klima. [online] Brno: Veronica, 2007. [cit. 2011-6-8] Dostupné z http: //www.veronica.cz/?id=247

Obsahuje popis vzdělávací výstavy Prima klima, která na dvanácti panelech vysvětluje, co je to skleníkový efekt, jak je pro nás důležitý, jaký je příspěvek člověka či jak fungují deštné pralesy z globálního hlediska. Navíc na velké části představuje jednotlivé dílčí oblasti, kde můžeme $v$ rámci opatření na osobní úrovni dosáhnout významných úspor.

\section{Velká výzva
$z$ http://www.velkavyzva.cz}

[online],

[cit.

2011-6-8]

Dostupné

Webové stránky nevládní ekologické organizace Hnutí Duha, která se snaží prosadit politická opatření na snižení emisí skleníkových plynů. Zajímavá ukázka, jak může vypadat "kampaň nevládní ekologické organizace, jaké používá prostředky a projevy občanské společnosti.

Bohouš a Dáša: klima v tísni. Praha: Člověk v tísni, 2009. ISBN 978-80-

$\begin{array}{llllll}86961-60-6 & \text { [online] } & \text { [cit. } & \text { 2011-6-8]. } & \text { Dostupné } & \text { z } \\ \text { http://www.varianty.cz/download/pdf/pdfs } & \text { 74.pdf } & & \end{array}$

Výukový materiál organizace zaměřené především na poskytování humanitární a rozvojové pomoc, která ale souběžně s tím vyvíjí své výukové moduly pro školy, např. Varianty. Na téma klimatu pohlíží výrazně ze společenskovědního a mezinárodněpolitického hlediska. Vhodné využití pro předměty Základy společenských věd a Dějepis.

Ukázky pracovních listů sdružení Tereza. [online] [cit. 2011-6-8]. Dostupné z http://lesveskole.terezanet.cz/pracovni-listy.html

Sdružení Tereza nabízí celou škálu ekologických výukových programů a pomůcek. Jejím prostřednictvím se mohou školy zapojit do mezinárodního programu Globe, změřeného na měření meteorologických veličin, bádání $v$ oblasti životního prostředí na globální i regionální úrovni apod. Na webu jsou k dispozici ukázky různých pracovních listů a výukových aktivit, s nimiž Ize pracovat $v$ rámci školního vyučování nebo mohou sloužit jako inspirace. s klimatem souvisí téma Les a klima a vztahy mezi nimi.

\section{Závěr}

Cílem textu byla snaha o uchopení globální změny klimatu ve výuce a její prezentace z různých úhlů pohledu. Tento způsob je z hlediska zpracování složitější, protože neposkytuje hotový návod pro výuku ani hotové vědecké "pravdy". Přestože bylo na toto téma zpracováno velké množství kvalitních vědeckých článků, její autoři sami zmiňují faktor nejistoty, především v oblasti scénářů směřujících do budoucnosti.

Bylo by jednoduché studentům prezentovat tuto tématiku jako sérii př́ícinných souvislostí (vzrůst objemu oxidu uhličitého rovná se vzrůst globální teploty) a pak prezentovat technologická řešení s velkými účinky (snížení emisí skleníkových plynů se 
sníží přímo úměrně teplota). Jak již bylo v textu naznačeno, klimatický systém je poměrně komplexní a proměnlivý a v rámci něj funguje celá řada komplikovaných zpětných vazeb. o to složitější je pak úkol pedagogů, jak toto téma zpracovat odpovídajícím způsobem pro studenty.

Dilematem vzdělávání je dále otázka přijetí odpovědnosti za problémy životního prostředí, tj. oblast postojových cílů, která je považována za jádro environmentální výchovy. Zejména bychom si měli položit otázku, čí to jsou problémy - má životní prostředí nějaké problémy, nebo má problém naše společnost, pro niž se podmínky životního prostředí, které svým pưsobením výrazně ovlivňuje, stávají pro život méně př́znivými.

Jakým způsobem o tomto problému učit dospívající mládež, která vstupuje do současného světa jako začínající spotřebitelé, cestovatelé, řidiči, pracující. Především není vhodný katastrofický tón. Cílem výuky by nemělo být vzbuzování pocitu viny, studu nebo strachu z budoucnosti - koneckonců odpovědnost za problémy, které zpưsobila generace rodičů, by neměla být přenášena na generaci, která se ve světě teprve "rozhlíží".

Psychologické výzkumy ukazují, že negativní zprávy, které mají tendenci vzbuzovat pocit viny, spíše alarmují únikové mechanismy psychiky a mohou ústit např́klad ve vytlačení tématu z mysli nebo jiným formám obrany (Krajhanzl a kol., 2010). v př́padě informování o nepř́znivých trendech zmiňme například, jak funguje jeden model sociálně psychologického chování, a to tzv. kognitivní dizonance. Jedná se o nesoulad mezi informacemi, které člověk dostává a jeho chováním, které subjektivně vnímá jako nelibý stav a snaží se navodit stav kognitivní konzonance. Příjemce může volit několik strategií, například alespoň drobnou změnu chování, nebo když se jedná o přiliš vážný problém, informaci jednoduše vytěsní.[17] (Librová, 1994:20)

\section{Na závěr bych si dovolila navrhnout několik doporučení:}

- $\quad$ environmentální problémy by neměly být prezentovány pouze v abstraktní rovině a zahlcovat studenty grafy, čísly a nic neříkajícími statistikami, ale měly by být vyváženy konkrétní vizualizací problému, nejlépe na regionální/lokální úrovni,

- $\quad$ prezentace každého environmentálního problému by měla být vyvážena ukázkou nebo alespoň představením reálné možnosti jeho řešení v osobní rovině, s ohledem na konkrétní cílovou skupinu a místo,

- $\quad$ určité formy proenvironmentálního chování by bylo vhodné povýšit na popisnou sociální normu. Sociální normy stanovují hranice lidského chování ve formě doporučení nebo oznámení, že se lidé v daném místě chovají určitým způsobem (Krajhanzl a kol 2010:26). v př́padě environmentálních sociálních norem je třeba dopředu připravit podmínky, a umožnit tak jejich realizaci. Kromě stávajících norem typu: neodhazujeme odpadky v lese, mladší uvolňují místo starším spolucestujícím v hromadném dopravním prostředku apod., by mohly patřit mezi základní environmentální normy například: ve škole i doma třídíme základní druhy odpadů včetně bioodpadu, na nákup používáme trvanlivé tašky místo jednorázových, dáváme přednost pitné vodě z kohoutku apod. [18]

V neposlední řadě slouží jako zajímavá inspirace literatura a filmy sci-fi, které rozvíjejí různé scénáře $v$ budoucnu. Studenti mohou diskutovat, jestli se ztotožňují spíše s filmy typu Den poté nebo 2012, s optimistickými scénáři série Star Trek, která ukazuje všestranně vyspělou multi-kosmicky-rasovou civilizaci 23. století (jež překonala někdejší problémy), prípadně s cynickou a ironickou sérií Futurama. Diskuse o budoucnosti a o tom, jak ji mohou mladí lidé formovat i ovlivňovat však začíná v tomto věku pomalu. Ale zcela jistě by měla patřit ke klíčovým kompetencím pedagogů. 


\section{Příloha 1: Didaktická analýza učebnice Ekologická a environmentální} výchova

Analýza didaktické efektivity učebního textu dle Obsta (OBST 2006: 42-45) se soustředí na zjištování rozložení aparátu prezentace učiva, aparátu řídícího učení a aparátu orientačním a jejich komponenty. Výsledek této didaktická analýzy učebnice vyjadřuje "relativní četnost komponent, které učebnice opravdu obsahuje". (OBST 2006: 42)

\section{MATĚJČEK, Tomáš. Ekologická a environmentální výchova. Praha: Nakladatelství České geografické společnosti, 2007. ISBN 978-80-86034-72-0}

I. Strukturní komponenty učebnice:

Aparát prezentace učiva:

A. verbální komponenty:

1. výkladový text prostý - ano

2. výkladový text zpřehledněný (přehledové tabulky, schémata aj.) - ano

3. shrnutí učiva k celému ročníku - ne

4. shrnutí učiva k tématům (kapitolám, lekcím) - ano

5. shrnutí učiva k předchozím tématům - ne

6. doplňující texty (citace, statistické tabulky apod.) - ano

7. poznámky a vysvětlivky - ano

8. podtexty k vyobrazením - ano

9. slovníčky pojmů, cizích slov apod. - ano

B. obrazové komponenty:

umělecké ilustrace - ne

fotografie - ano

3. nauková ilustrace (schématické kresby, náčrty, modely) - ano

4. grafy, diagramy - ano

5. obrazová prezentace barevná - ano

$\mathrm{V}$ učebnici zjištěno 11 komponent, tj. koeficient využití aparátu prezentace učiva:

\section{$E I=11 / 14 \times 100=79 \%$.}

II. Aparát řídící učení:

C. verbální komponenty:

1. předmluva (úvod do předmětu) - ano

2. návod k práci s učebnicí ( $v$ kapitole Úvod) - ano

3. stimulace celková (podněty k zajištění, otázky) - ano

4. stimulace detailní (podněty $v$ průběhu lekce) - ano 
5. otázky a úkoly za lekcí - ano

6. otázky a úkoly za tématy - ne

7. otázky a úlohy k celému ročníku (opakování) - ne

8. otázky a úlohy k předchozímu ročníku - ne

9. instrukce k úkolům komplexnější povahy - ne

10. náměty pro mimoškolní činnost - ano

11. explicitní vyjádření cílů pro žáky - ne

12. sebehodnocení pro žáky (testy apod) - ano

13. výsledky úkolů a cvičení - ne

14. odkazy na jiné zdroje informací - ano

D. obrazové komponenty:

1. grafické symboly - ano

2. užití zvláštní barvy pro určité části textu - ano

3. využití předsádky (schémata, tabulky) - ano

4. užití zvláštního písma - ano

$\mathrm{V}$ učebnici zjištěno 6 komponent, tj. koeficient využití aparátu řídícího učení: $E I I=13 / 18 \times 100=72 \%$.

III. Aparát orientační

E. verbální komponenty

1. obsah učebnice - ano

2. členění na tematické celky, kapitoly apod. - ano

3. marginálie (pozn. na okraji stránky) - ne

4. rejstř́k - ne

V učebnici zjištěny 2 komponenty, tj. koeficient využití aparátu orientačního

EIII $=2 / 4 \times 100=50 \%$

Celkový koeficient učebnice (E) je průměrem dílčích aparátů, tj. EI 79 \%, EII 72 $\%$ a EIII $50 \%$, tj E= $67 \%$.

Tato učebnice má poměrně vysokou hodnotu - $67 \%$ didaktické efektivity. Pro účely vytvoření výukové jednotky bychom se tedy neměli spokojit s jednou učebnicí, ale použít další zdroje, a to nejen učební texty, a soustředit se již více na obsahovou stránku. 


\section{Příloha 2: Ukázka výukové jednotky pro využití v průřezovém tématu Environmentální výchova}

...na základě použití některých z výše uvedených pramenů [19]

Zvolený přístup k výuce vychází z kognitivně - psychologických teorií, konkrétně pedagogického konstruktivismu. Tento přístup se snaží překonat převažující přednáškový styl výuky, kdy pedagog jednosměrně přenáší definitivní informace žákùm a studentům, ale naopak vyžaduje po studentech, aby si významy a porozumění sami konstruovali z předložených informací. Učitel je jejich pouhým průvodcem na "trnité" cestě za poznáním (upraveno dle Obst, 2006:12-13).

\section{Název: Planeta Země: seznamte se}

Tematický celek : Základní podmínky života

Zpracovaná témata: Planeta Země - náš domov ve vesmíru. Přírodní zdroje. Voda. Ovzduší. Pưda. Biodiverzita.

Rozvržení výuky :2-3 vyučovací hodiny (2-3x45 minut) a společnost

Vzdělávací oblasti: Člověk a příroda, Člověk a životní prostředí, Člověk

Klíčové kompetence: schopnost kritického myšlení a hledání souvislostí, práce s informacemi a jejich vyhodnocování, komunikace a spolupráce se spolužáky apod.

Pomůcky: globus, obrázky schémat, pracovní listy, tvrdé papíry A3, fixy, barevné pastelky, internet, učebnice, informační prameny

Výukové metody: aktivizující a problémové metody(aktivity: skupinová práce, brainstorming, myšlenková mapa, řízená diskuse, dialog v kruhu, výtvarné a tvořivé aktivity)

Doporučený ročník : 9. ročník ZŠ, SŠ

\section{Výukové cíle:}

Obecné cíle:

- Studenti si uvědomují širší souvislosti mezi životními podmínkami Země (včetně klimatického systému) a společností. Základním poznatkem je závislost naší společnosti na stávajících životních podmínkách a nutnost vyrovnat se různými prostředky s měnícími se životními podmínkami (včetně variability klimatického systému Země).

\section{Kognitivní cíle:}

- $\quad$ studenti vyjmenují a popíší základní podmínky Země a její jednotlivé složky

- $\quad$ studenti definují a rozliší základní pojmy, např.: atmosféra, biosféra, hydrosféra, skleníkový efekt, skleníkové plyny, sluneční záření a jeho složky, klima, počasí, solární konstanta, ekosystémové služby, radiační bilance

Postojové cíle:

- $\quad$ studenti si uvědomují, že naše společnost závisí na určitých životních podmínkách, 
- které jsou na planetě Zemi pro náš druh relativně příznivé

- studenti zhodnotí ekosystémové služby a jejich praktický (nejen ekonomický) význam pro společnost

\section{Výcvikové cíle:}

- studenti ovládají práci s myšlenkovou mapou

- Studenti jsou schopni popsat různé procesy na základě názorných obrázků a grafů

- studenti umí prezentovat a přednést ostatním výsledky své skupinové práce

- $\quad$ studenti spolupracují ve skupině, rozdělí si role

\section{Prekoncepty, s kterými studenti přicházejí do hodiny:}

Znalosti o planetě Zemi jsou kusé, nesourodé, velmi abstraktní a studenti je neumí spojit s reálnými př́klady. Nejsou schopni dávat jednotlivé informace, které obdrželi $v$ různých předmětech, do širších souvislostí. Nemají přesnou představu o fungování klimatického systému, skleníkovém efektu a neumí zhodnotit míru vlivu lidské společnosti na životní prostředí a biosféru. Používají cizí pojmy bez bližší představy o tom, co konkrétně znamenají.

\section{Evokace}

Pedagog uvede studenty do situace: vesmírná sonda mimozemštanů je na průzkumné plavbě vesmírným prostorem, monitoruje Sluneční soustavu. Hledá planetu s príhodnými podmínkami vhodnými pro život. Jako základní podmínky si stanoví: stabilní životní podmínky, fungující atmosféra, naleziště vody, výskyt kyslíku ve vzduchu.[20]

Žáci se rozdělí do 8 skupin (podle planet ve Sluneční soustavě) a mají za úkol zjistit stručné informace o jednotlivých planetách (stáří, velikost, vzdálenost od Slunce, složení atmosféry a povrchu, délka oběhu kolem Slunce apod.) z různých informačních pramenů. Postupně své planety nakreslí, zpracují a zapíší údaje. Poté je prezentují a porovnávají, zda splňují zadané parametry.

\section{Uvědomění si významu}

Nyní se logicky dostaneme k bližšímu popisu planety Země a jejích příznivých podmínek pro vznik a existenci života. Pedagog vezme globus a postupně povzbuzuje žáky, aby si vzpomněli na jednotlivé příklady, případně pomůže s bližším popisem jejich významu:

- Země obíhá kolem Slunce v přiměřené vzdálenosti (cca 150 mil. km), což umožňuje zachování vody na planetě. Kdyby byla blíž Slunci, voda by se vypařila, při delší vzdálenosti by naopak zmrzla. Má také přiměřenou velikost a gravitaci potřebnou $k$ tomu, aby vodu udržela.

- Důležitý je také sklon zemské osy $\left(23^{\circ} 27^{\prime}\right)$ a stř́dání dne a noci. Zabraňuje nadměrnému přehřátí jedné polokoule nebo promrznutí druhé polokoule.

- Velký význam pro zachování života má také Slunce, které poskytuje Zemi poměrně stabilní množství energie ze slunečního záření, která je hlavním hybatelem prírodních procesů na Zemi, jako jsou koloběh vody, meteorologické jevy, fotosyntéza apod.

- Země disponuje ochrannými obaly proti škodlivým vlivům z vesmíru. Magnetické pole poskytuje ochranu před částicovým zářením ze Slunce (sluneční vítr). Atmosféra, 
plynný obal Země, obsahuje vrstvy, které ochraňují planetu Zemi před některými škodlivými složkami slunečního záření - např́klad ozonosféra pohlcuje ultrafialové záření. Obsahuje také v ideálním poměru plyny především dusík (78 \%), kyslík (21 \%), argon $(0,93 \%)$, dále oxid uhličitý $(0,03 \%)$, metan $(0,00017 \%)$, proměnlivé množství vodní páry, aerosoly a stopové množství vzácných plynů

- Další složkou je hydrosféra, vodní obal Země, která je důležitým regulátorem podnebí. Díky schopnosti zadržovat teplo (měrná tepelná kapacita) vyrovnává teplotní rozdíly mezi ročními obdobími i dnem a nocí. Díky obsahu vody ve třech skupenstvích (plynné, kapalné, pevné) slouží jako ekosféra - pás, který umožňuje rozvoj organického života.

- Základní podmínkou pro vznik a udržení života je pedosféra a její úrodná vrstva humusu, kterýumožňuje růst vegetace a zároveň je životním prostorem mnoha druhů živočichů. Půda je dále důležitou součástí koloběhu různých látek včetně uhlíku a je také jeho velkou zásobárnou.

- Skleníkový efektumožňuje udržet na Zemi poměrně stabilní průměrnou teplotu cca $15{ }^{\circ} \mathrm{C}$, jinak by zde docházelo k velkým teplotním výkyvům. Některé plyny $v$ atmosféře mají schopnost pohlcovat a vysílat infračervené paprsky, které zpětně vyzařuje zahřátý povrch Země od slunečního záření, jehož část pronikla a ohřála povrch planety. Plyny dusík a kyslík, které tvoří převážnou většinu atmosféry (99\%), záření ani nepohlcují ani nevysílají. Především vodní pára, oxid uhličitý a metan určitou část tepelného záření, jež opouští povrch Země, pohlcují a zpomalují únik tepla zpět do vesmírného prostoru. Tyto plyny pưsobí tedy na vyzařování jako částečná "pokrývka".

- Velký význam má desková tektonika (pohyb litosférických desek), které umožňují oběh životně důležitých látek (fosfor, uhlík, dusík).

- Na Zemi se vyvinul život v mnoha různých formách, tomuto bohatství ríkáme biodiverzita. Tohoto "bohatství" využívá i člověk ke svému prospěchu (zdroj potravy, léčiva apod.). Život na planetě Zemi se mohl vyvinout jen díky shodě různých příznivých okolností a díky relativně stabilnímu fungování životadárných systémů. Přestože planeta za dobu své existence (4,6 mld. let) prošla několika katastrofami, které téměř zpưsobily vyhlazení života na jejím povrchu, ten se vždy obnovil a opět rozvíjel. Díky vzrưstajícímu vlivu činnosti člověka na její životní podmínky se začínají objevovat spekulace, že způsobuje $v$ pořadí šesté hromadné vymírání druhů (měrou zásahů do ekosystémů a složek Země).

\section{Reflexe 1: Aktivita Myšlenková mapa[21]}

Doprostřed tabule napíše pedagog klíčový pojem ( $v$ tomto případě Země) a studenti postupně připisují šipky a související pojmy. Hledají tedy postavení Země ve vesmíru a životní podmínky, které poskytují příznivé prostředí pro rozvoj života. Pojmy se budou dále větvit (podstatou myšlenkovým map je, že se mohou rozvětvovat). Studenti mohou také dále domýšlet souvislosti, co by se stalo (případně co se již stalo), kdyby došlo k ovlivnění či narušení složek Země apod. Fantazii se meze nekladou. Neexistují mapy s autorským řešením. Jde o to, aby studenti rozvíjeli své myšlenkové pochody. Myšlenkové mapy Ize tvořit na podrobnější úrovni, kdy klíčové pojmy budou tvořit jednotlivé složky na základě předchozího textu (např. atmosféra).

\section{Obr 1: Ukázka rozpracované myšlenkové mapy, kterou Ize libovolně dále doplňovat}




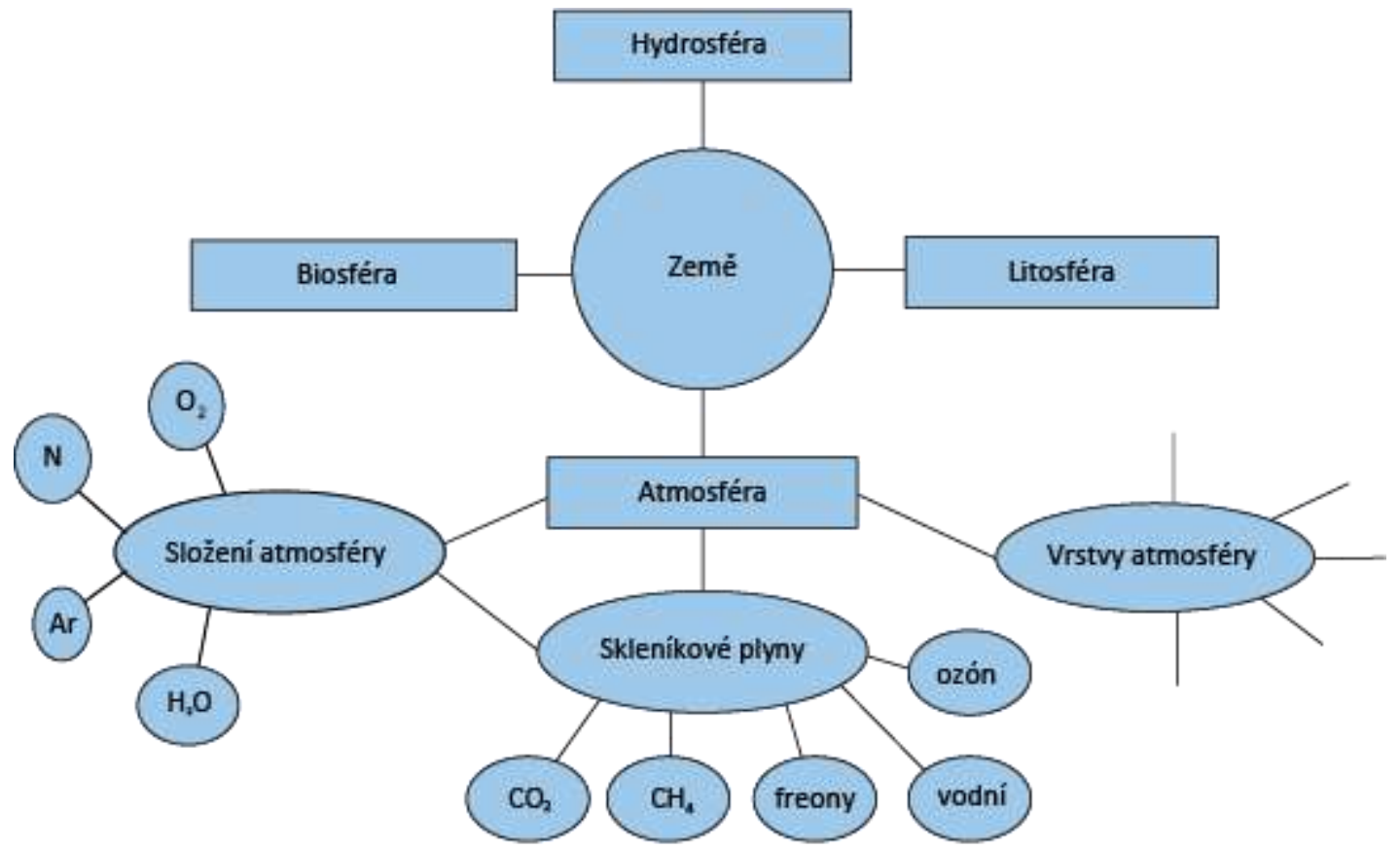

Zdroj: vlastní na základě dostupných dat

\section{Reflexe 2: Aktivita Ekosystémové služby Země}

Studenti se pokusí vyhodnotit služby, které lidstvu poskytují jednotlivé ekosystémy a složky Země. Vytvoří si jednoduchou tabulku a doplňují jednotlivé kategorie u konkrétních přikladů. Tyto služby Ize rozdělit do základních kategorií: zásobovací, regulační a kulturní služby.

Príklady zásobovacích služeb: voda, potraviny, prostor, prírodní zdroje (suroviny) a energetické zdroje, textilní vlákna, genetické zdroje, léčiva.

Př́ílady regulačních služeb: regulace kvality ovzduší, regulace klimatu, regulace eroze, čištění vody a likvidace odpadů, regulace chorob, škůdců, opylení, regulace př́rodních pohrom (např. záplavy).

Příklady kulturních služeb: duchovní a náboženské hodnoty, estetické hodnoty, rekreace, turistika.

Příklady pro další hodnocení: oceány, atmosféra, půda, lesy, mokřady, uhelné ložisko, horský ledovec. 


\section{SLUŽBA ZÁSOBOVACÍ}

zdroj dřeva (nábytek, papír, topení atd.)

lesní plody, houby, lesní zvěř

\section{SLUŽBY REGULAČNÍ}

pozitivně ovlivňuje klima - je zde větší vlhkost, stín

prostřednictvím fotosyntézy pohlcuje oxid uhličitý a vyrábí kyslík

les účinně zadržuje vodu (v půdě, listech, kořenech)

kořeny stromů zpevňují půdu

les přispívá k tvorbě půdy a humusu (opadanka, rozpadající se dřevo)

lesní půda je významným úložištěm uhlíku

\section{KULTURNÍ SLUŽBY}

místo pro aktivní i pasivní odpočinek, turistiku

památné stromy - historická a prrírodní hodnota

statut ochrany - prírodní hodnoty

možnost výtvarného a uměleckého zobrazení

celkově pozitivní zdravotní, regenerační účinky

\section{Zdroj: vlastní zpracování na základě dostupných informací}

\section{Otázky k zamyšlení}

můžeme na LES nahlížet jen z hlediska "užitečnosti" pro člověka, nemá hodnotu samu o sobě? Na les můžeme také nahlížet $z$ tohoto pohledu: je to svébytný ekosystém, poskytuje životní prostor pro řadu živočišných a rostlinných druhů. Les bez vlivu člověka bez problémů přežije (právě naopak), zatímco člověk je na lese existenčně závislý.

Další aktivita (možnost využití v úvodu, nebo na závěr jako reflexe)

Jeden vědec se pokusil definovat pojmy, s kterými budeme ve výuce pracovat. Bohužel to všechno popletl. Studenti přiřadí správné definice $\mathrm{k}$ pojmům:

počasí

přirozeného původu jsou vodní pára, oxid uhličitý a metan; antropogenního původu jsou oxid uhličitý, metan, oxid dusný, částečně a zcela fluorované uhlovodíky, fluorid sírový, freony. 


\begin{tabular}{|c|c|}
\hline klima & je část planety Země, kde se vyskytují formy života. \\
\hline $\begin{array}{l}\text { klimatický } \\
\text { systém }\end{array}$ & $\begin{array}{l}\text { přerušovaný zemský obal vytvořený ledem, sněhem a dlouhodobě } \\
\text { zamrzlou půdou. }\end{array}$ \\
\hline kryosféra & plynný obal Země. \\
\hline biosféra & $\begin{array}{l}\text { představuje základní zdroj energie pro veškeré procesy probíhající } \\
\text { v atmosféře a na zemském povrchu. Příkon záření dopadajícího na } \\
\text { povrch zemské atmosféry je cca } 1370 \mathrm{~W} / \mathrm{m} 2 \text { - toto množství se nazývá } \\
\text { solární konstanta. }\end{array}$ \\
\hline atmosféra & $\begin{array}{l}\text { okamžitý stav ovzduší na určitém místě. Je dáno stavem všech } \\
\text { atmosférických jevů pozorovaných na určitém místě a v určitém } \\
\text { krátkém časovém úseku nebo okamžiku. }\end{array}$ \\
\hline $\begin{array}{l}\text { sluneční } \\
\text { záření }\end{array}$ & $\begin{array}{l}\text { pevný obal Země tvořený zemskou kůrou a nejsvrchnějšími vrstvami } \\
\text { zemského pláště. Její tloušt'ka se pohybuje obvykle v rozpětí } 70-100 \\
\text { km. }\end{array}$ \\
\hline litosféra & $\begin{array}{l}\text { systém, který se skládá z atmosféry, hydrosféry, kryosféry, zemského } \\
\text { povrchu a biosféry a zahrnuje i jejich vzájemné vazby. }\end{array}$ \\
\hline $\begin{array}{l}\text { skleníkový } \\
\text { efekt }\end{array}$ & $\begin{array}{l}\text { Země stále pohlcuje krátkovlnné sluneční záření a vydává dlouhovlnné } \\
\text { zářní, poměr se mění ve dne, v noci, v průběhu ročních období i na } \\
\text { různých místech planety. }\end{array}$ \\
\hline $\begin{array}{l}\text { radiační } \\
\text { bilance }\end{array}$ & $\begin{array}{l}\text { dlouhodobý stav počasí, podmíněný energetickou bilancí, cirkulací } \\
\text { atmosféry, charakterem aktivního povrchu a dnes i člověkem. Změny } \\
\text { probíhají v dlouhodobých časových úsecích. }\end{array}$ \\
\hline troposféra & $\begin{array}{l}\text { proces, při kterém atmosféra způsobuje ohřívání planety tím, že } \\
\text { absorbuje dopadající sluneční záření a zároveň částečně brání jeho } \\
\text { zpětnému odrazu do vesmírného prostoru. }\end{array}$ \\
\hline $\begin{array}{l}\text { skleníkové } \\
\text { plyny }\end{array}$ & $\begin{array}{l}\text { vrstva atmosféry od zemského povrchu do zhruba } 10 \text { až } 15 \text { kilometrù. } \\
\text { Odehrává se zde naprostá většina toho, co ovlivñuje náš život. Veškeré } \\
\text { povětrnostní jevy jako povětrnostní fronty, srážky a proudění vzduchu } \\
\text { se omezují prakticky na tuto vrstvu atmosféry. }\end{array}$ \\
\hline albedo & odrazivost slunečního záření zpět do vesmíru (mraky, sníh). \\
\hline
\end{tabular}




\section{Seznam použité literatury}

\section{Tištěné prameny:}

- Behrlinger, W. (2010). Kulturní dějiny klimatu: Od doby ledové po globální oteplování. Praha: Paseka.

- $\quad$ Bell, M. (2012). Invitation to Environmental Sociology. Los Angeles: SAGE.

- HARPER, Ch. L, (2011) Environment and Society: Human Perspectives on Environmental Issues. In Chapter 3: Climate Change, Science, and Risk (pp. 61-90). New Yersey: Prentice Hall.

- Gore, A. (2007). Nepř́jemná pravda: Naše planeta v ohrožení - globální oteplování a co s ním můžeme udělat. Praha: Argo.

- Kopp, J., \& Beránková, L. (2012). Testování úrovně znalostí o změnách klimatu. Informace ČGS, 31(1), 18-29.

- KRAJHANZL, Jan a kol, (2010). Možnosti spolupráce s veřejností nejen při ochraně životního prostředí. Praha: Zelený kruh.

- Kutílek, M. (2008). Racionálně o globálním oteplování. Praha: Dokořán.

- Librová, H. (1994). Pestrí a zelení. Brno: Veronica, Hnutí Duha.

- Lomborg, B. (2008). Zchladite hlavy. Skeptický ekolog o globálním oteplování. Praha: Dokořán.

- Maňák, J., \& Klapko, D. (eds.), (2006). Učebnice pod lupou. Brno: PAIDO.

- Marek, V.M. a kol, (2011). Uhlík v ekosystémech České republiky v měnícím se klimatu. Praha: Academia.

- Matějček, T. (2007). Ekologická a environmentální výchova. Praha: Nakladatelství České geografické společnosti.

- Nicholson-cole, S. A. (2005). Representing climate change futures: a critique on the use of images for visual communication. Computers, Environment and Urban Systems, 25(2005), 255-277. Retrieved from http://linkinghub.elsevier.com/retrieve/pii/S0198971504000389 http://dx.doi.org/10.1016/j.compenvurbsys.2004.05.002

- Obst, O. (2006). Didaktika sekundárního vzdělávání. Olomouc: Pedagogická fakulta Univerzity Palackého.

- ShepardSON, D. a kol, (2012). Seventh Grade Students' Mental Models of the Greenhouse Effect. Environmental Education Research, 17(1), 1-17.

- REID, Walter W. a kol, (2005). Ekosystémy a lidský blahobyt. Syntéza. Praha: Centrum UK pro otázky životního prostředí.

- Voženílek, Vít a kol, (2010). Klimatická změna v e-learningové výuce. Olomouc: Univerzita Palackého.

- Weber, E. U. (2010). What shapes perception of climate change?. Wires Climate Change, 1(3), 332-342. Retrieved from http://doi.wiley.com/10.1002/wcc.41 http://dx.doi.org/10.1002/wcc.41

- Bohouš a Dáša: Klima v tísni (2009). Praha: Člověk v tísni. Retrieved from http://www.varianty.cz/download/pdf/pdfs 74.pdf

- ČESKÝ překlad dokumentů IPCC (2007) [Online] (2007). . Retrieved from http://www.mzp.cz/cz/vedecke poznatky 
- Dlouhá, J. . Kompetence v environmentálním vzdělávání. Envigogika, 4(1), Retrieved from http://www.envigogika.cuni.cz/

- GLOBÁLNí změna v kostce (2010). Brno: Centrum výzkumu globální změny. Retrieved from http://www.czechglobe.cz/index.php?option=com content $\& v$ iew $=$ article\&id $=78 \&$ Itemid $=26 \& l$ $\underline{\text { ang }=\mathrm{CS}}$

- Metelka, L., Tolasz, R., (2009). Klimatické změny: Fakta bez mýtů.. Praha: Centrum UK pro otázky životního prostredí,. http://www.czp.cuni.cz/knihovna/publikace/klimaticke-zmeny-web.pdf

- $\quad$ METODICKÝ pokyn MŠMT k zajištění environmentálního vzdělávání, výchovy a osvěty (2008). Praha: MŠMT. Retrieved from http://www.msmt.cz/vzdelavani/metodicky-pokyn-msmt-kzajisteni-environmentalniho

- UKÁZKY pracovních listů sdružení Tereza. [online] . . Retrieved from http://lesveskole.terezanet.cz/pracovni-listy.html

- VÝSTAVA Prima klima. (2007). Brno: Veronica. Retrieved from http://www.veronica.cz/?id=247

\section{Poděkování}

Autorka děkuje za podporu projektu CzechGlobe - Centrum pro studium dopadu globální změny klimatu (CZ.1.05/1.1.00/02.0073), s podporou na dlouhodobý koncepční rozvoj výzkumné organice RVO:67179843 a projektu „Partnerství v oblasti výzkumu klimatu a adaptačních strategií " (CZ.1.07/2.4.00/31.0056).

Mgr. Barbora Duží

Centrum pro studium dopadu globální změny klimatu

Oddělení Adaptačních strategií

Bělidla 986/4a,

60300 Brno

Česká republika

[1] Environmentální výchova je zpravidla vyučována jako samostatný předmět, nebo je součástí výuky předmětu Ekologie či dalších předmětů. 
[2] v této studii pracuji s Bloomovou taxonomií vzdělávacích cílů, která poskytla teoretický základ pro kategorizaci výukových cílů (kognitivní, afektivní a psychomotorické) a myšlenkových operací (znalosti, porozumění, aplikace, analýza, hodnocení, syntéza) v procesu vzdělávání. Také s klíčovými kompetencemi (k učení, řešení problémů, občanské, sociální a personální, pracovní), které vhodně kombinují uvedené předpoklady a kladou důraz na jejich praktickou aplikaci v konkrétních situacích (Obst, 2006). v poslední době dochází k revizi Bloomovy taxonomie a posunu k dynamičtější koncepci kombinace vzdělávacích cílů s kompetencemi, přičemž právě na ovládání (klíčových) kompetencí je kladen větší dưraz (tento posun vysvětluje blíže např. Dlouhá, 2009).

[3] Např. studie Římského klubu - Limity růstu (1972), Překročení mezí (1992), výstupy World Watch Institute apod.

[4] v anglické terminologii "social amplification". Existuje samozřejmě více koncepcí analyzující percepci a interpretaci environmentálních problémů, např. sociální konstrukce reality nebo analýza diskursu. Koncept social amplification jsem zvolila z důvodu, že je relevantní především k informační stránce sdělení.

[5] Nevládní ekologické organizace, průmyslové společnosti, PR firmy, média apod. Týká se to svým způsobem i pedagogických pracovníků, protože jejich osobní postoj odráží i to, jak danou problematiku prezentují studentům.

[6] Mezi extrémní opatření patří návrh na vypuštění prachu do stratosféry, železa do moří pro stimulaci růstu planktonu v oceánech. Mezi reálnější návrhy patří injektáž oxidu uhličitého do pískovcových skal. Zajímavý dokument, pojednávající o těchto opatřeních, je Hot Planet (2009) z dílny BBC.

[7] Mezi další průřezová témata patří: Osobnostní a sociální výchova, Výchova demokratického občana, Výchova k myšlení vevropských a globálních souvislostech, Multikulturní výchova, Mediální výchova.

[8] Pro potřeby této práce nebudu rozebírat vývoj ekologické/environmentální výchovy a její postupné implementace do školského systému. Vycházím ze současného stavu, kdy je toto téma rovnocenně zařazeno jako průřezové téma do škol, i když tomu tak $v$ minulosti nebylo a současný stav je výsledkem dlouhodobého a systematického snažení především pracovníků středisek ekologické výchovy.

[9] Přiměřená vzdálenost Země od Slunce, stabilní množství energie vztahující se na záření od Slunce, "ochranná vrstva" planety Země atmosféra, odstiňující negativní účinky některých složek slunečního záření a uchovávající relativně stabilní životní podmínky bez velkých výkyvů (ozonová vrstva, magnetické pole, skleníkový efekt), výskyt vody na planetě ve třech skupenstvích apod.

[10] Tento způsob života, respektive chování, bývá označen různými způsoby, např. jako environmentálně příznivý zpưsob života (Hana Librová), nebo výběrová náročnost (Erazim Kohák), v ekopsychologické literatuře se používá pojem proenvironmentální chování ( $v$ českém prostředí používá např. Jan Krajhanzl).

[11] Mezi základní miskoncepce autoři identifikovali např́klad nevhodný výklad principu skleníkového jevu podle skleníku nebo nevhodné propojování principu skleníkového jevu s problematikou ozonové vrstvy. Zde je třeba uvést poznámku, zda nástroj spočívající v príměru ke skleníku byl zvolen vhodným způsobem. Pro řadu složitých vědeckých problémů se hledá vhodné přirovnání, konstrukce umožňující snadnější pochopení, někdy ale tento nástroj může sám o sobě přispět k miskoncepcím, jako, dle mého názoru, v př́padě skleníku. Tento názor jsem našla potvrzen i ve výzkumu mentálních modelů a kvalitě prezentace v učebnicích (NICHOLSON-COLE 2005:2). Problematiku sociální konstrukce vědeckých problémů vhodně rozebírá např. Bell (2012), který zmiňuje i př́klad ozonové "díry", který vědci zvolili pro přirovnání ke "ztenčování ozonové vrstvy". 
[12] Zohlednění klimatických faktorů a jejich vlivu na lidskou společnost je zajímavé například v historii - migrace obyvatel, válečné konflikty, příčiny čarodějnických procesů ve středověku, prričiny expanze i kolapsư velkých říši nebo izolovaných společností v rámci hodin dějepisu apod. Inspirativní je v tomto smyslu kniha autora Wolfganga Behringera: Kulturní dějiny klimatu (2010).

[13] Samozřejmě ani vědecké týmy nezastávají stejný názor na problematiku klimatické změny a možného antropogenního vlivu, kromě toho i věda samotná vychází z určitého sociálního kontextu.

[14] Zajímavé jsou výsledky sociologického šetření množství a kvality novinových článkư a tématu klimatických změn v průběhu 10 let - 1997-2007. Byly analyzovány články Hospodářských novin, Práva, Mladé fronty DNES, Lidových novin, Haló novin. Co se týče počtu článků, jejich počet každým rokem strmě vzrůstal, naopak se každým rokem snižovala komplexnost informací obsažených $v$ článcích, z toho plynula i nespokojenost respondentů - čtenářơ s kvalitou a obsahem článků (zpracováno dle Marek a kol., 2010: 221-223).

[15] Uvedené grafické znázornění si v žádném př́padě neklade nároky na odpovídající vědeckou hodnotu. Jde spíše o kvalitativní zhodnocení po prostudování a analýze publikací dle určitých kritérií.

[16] Kalkulačka uhlíkové stopy spočítá produkci skleníkových plynů v oblastech, které výrazně emise ovlivňují - při spotřebě energie v domech a bytech, v dopravě, uložené $v$ materiálech apod. k jejímu výpočtu je třeba znát roční spotřebu elektřiny, zemního plynu a dalších energií ( $v$ jednotkách kWh).

[17] Jedná se o zjednodušený příklad, celá problematika je složitější. o tom, jakým způsobem komunikovat problémy životního prostředí směrem k veřejnosti, se zabývá publikace KRAJHANZL a kol (2010): Možnost spolupráce s veřejností nejen při ochraně životního prostředí. Do určité míry je využitelná i pro zpưsoby komunikace pedagog studenti.

[18] v rámci předmětu environmentální výchova si mohou studenti zkusit navrhnout dané sociální normy sami. Mohou si pak dělat zpětnou vazbu a průběžně hodnotit (ne)úspěšnost jejich dodržování a rozebrat, co jim bránilo v jejich dodržování. Byla to jen lenost a pohodlí, nebo šlo o reálné překážky? Řada příkladů je obsažena například v publikacích obsahujících doporučení v oblasti environmentálně šetrného chování (Vlašín a kol. Desatero domácí ekologie, 2010; Havel, M. a kol. Jak žít dobře, zdravě a ekologicky šetrně, 2010).

[19] Mohu poskytnout zpracované další výukové jednotky obsahující práci s pojmy, schématy a další aktivity. v případě zájmu pište na arobrab@centrum.cz.

[20] Zajímavá by byla diskuse se studenty o fenoménu mimozemštanů. u dospívajících je ve velké oblibě sci-fi literatura i filmy, které se zabývají různými formami setkání/střetu s mimozemskými civilizacemi, dalším oblíbeným tématem je eskalace některých problémů (epidemie, zdroje energie, klimatické změny, klonování apod.).

[21] Myšlenková mapa je diagram, který se používá pro vizualizaci a záznam myšlenek. Ve středu tohoto diagramu je tzv. klíčové téma. Od tohoto tématu se postupně navazují další a další klíčové slova dle souvislostí a vazeb, na které se postupně přichází, včetně dalších pojmů různé úrovně. Myšlenkovou mapu Ize využít na rozkreslení celé řady témat, a to nejen environmentálních. 
Časopis Envigogika vydává Centrum pro otázky životního prostředí UK. Vývoj časopisu je podpořen projektem OP VK Mezioborová sít udržitelného rozvoje.

Více najdete na internetových stránkách projektu http://mosur.czp.cuni.cz
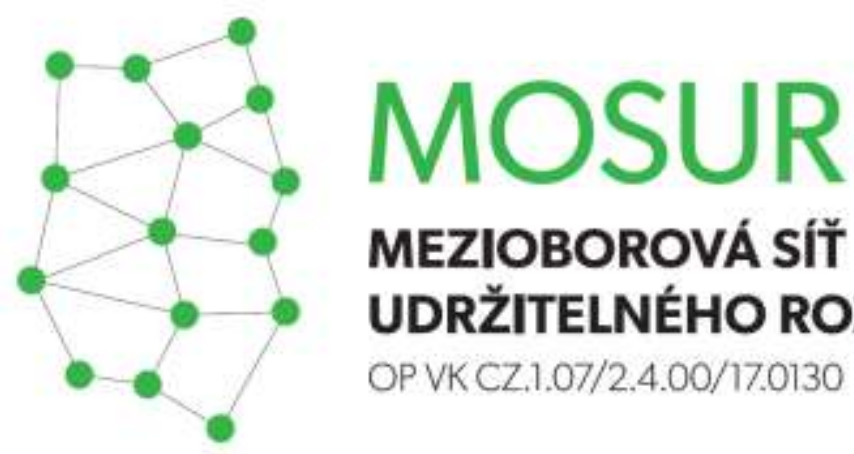

\section{MEZIOBOROVÁ SÍT}

UDRŽITELNÉHO ROZVOJE

OP VK CZ.1.07/2.4.00/17.0130
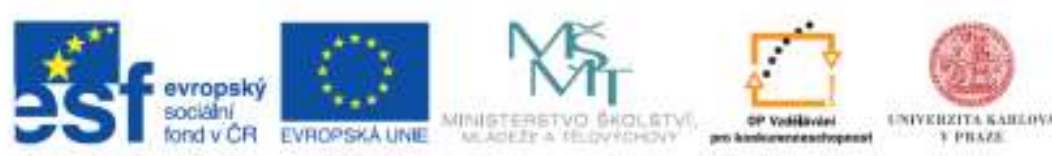

INVESTICE DO ROZVOJE VZDELAVANI 